Ж. М. Свірська

\title{
ЕКЗИСТЕНЦЙНЕ НАПОВНЕННЯ АРХЕТИПІВ, ОПРИЯВЛЕНИХ У ТВОРЧОСТІ БОГДАНА-ІГОРЯ АНТОНИЧА
}

Свірська Ж. М. Екзистенційне наповнення архетипів, оприявлених у творчості Богдана-Ігоря Антонича.

У статті проведено спостереження за системою прийомів художнього мислення Богдана-Ігоря Антонича, розкрито самобутність поетичного світу та коди віршів. Лірика дає широкий простір для аналізу архетипів у межах суб'єктивного досвіду. Проілюстровано, що художньо-філософська концепція митця утверджує єдність світу, космосу, залучає людину в коло життя як органічну частку природи. Доведено, що тонкі нюанси бачення світу, порухи у свідомості «Я»-автора, які втілюються в індивідуальних метафорах, побудованих на переосмисленні архетипних образів.

(с) Ж. М. Свірська, 2016.

-236- 
Ключові слова: архетипні структури, поетична концепція світу, поетика.

Свирская Ж. Н. Экзистенциональное наполнение архетипов, проявленных в творчестве Богдана-Ігоря Антонича

В статье проведено наблюдение за системой приёмов художественного мышления Богдана-Игоря Антонича поэта, раскрыто самобытность поэтического мира и коды стихов. Лирика дает широкие просторы для анализа архетипов. Пролюстрировано, что художественно-философская концепция творца утверждает единство мира, космоса, включая человека в круг жизни как органическую частицу природы. Доказано, что тонкие нюансы видения мира, сдвиги в сознании «Я»-автора реализовываются в индивидуальных метафорах, построенных на переосмыслении архетипных образов.

Ключевые слова: архетипные структуры, поетическая концепция мира, поэтика.

Svirs'ka Zh. M. Existential content of archetypes embodied in works of Bohdan-Ihor Antonych.

The system methods of artistic thinking of the poet is being monitored in the article, disclosed the identity of the poetic world and poetry codes. Lyrics gives a broad space for the analysis of archetypes within the framework subjective experience. It was illustrated that artistic and philosophical conception of the artist claims the unity of the world, the cosmos, including the man in the circle of life as an organic particle nature.

It was proved that intimate, private, emphatically self-centered thematic-ideological core of Bohdan-Ihor Antonych heritage intertwines very closely with massive structures and archetypal images that are inherent in the deep layers of national consciousness. Creator raises the issue of subtle nuances of seeing the world, shifts in the consciousness of author's "I", which are realized in individual metaphors, built on rethinking archetypal images. Mythopoetic aspect of the analysis enabled the demonstration of flexibility and relevance of artist's literary archetypes.

Under the influence of historical and social changes any archetype fixed in literary works, reveals a fresh, timeless content "built in" author's intention and implemented in the poetry pieces. Archetype images are deeply rooted into personal consciousness of a lyric character and serve as a starting point for collecting associations, mythologem codes in different levels, ethnic, national and cultural reminiscence. Enormous semantic content richness, complex symbolic and figurative structure, exquisite metaphors, demanding time and space chimeras give a special sort of aesthetic pleasure while reading the works by B.-I. Antonych.

Key words: archetypal structure, poetry conception of the world, poetics.

Інтимний, приватний, підкреслено егоцентричний тематикоідейний стрижень доробку Богдана-Ігоря Антонича якнайтісніше переплітається із масивними, властивими глибинним шарам національної свідомості архетипними структурами та образами. Модерність бачення, сміливість мистецького почерку, оригінальність 
специфічної, упізнаваної сенсобуттєвої й світобудовної візії - усе робить поезію Антонича зрозумілою сучасному читачеві. Незаперечна художня цілісність творчого внеску створюють для дослідника привабливе поле для аналізу поетики архетипних образів.

Створений художній універсум у найкращих проявах презентує кожному новому поколінню читачів і дослідників ліро-філософську парадигму існування індивіда, органічно вписану в гармонійне вселенське буття. Багатовимірність образної системи Антонича грунтується на діалектичній єдності архетипних понять і міфологем, що за традицією осмислюються скоріш як дихотомічні: людина Всесвіт, живе - неживе, світ індивіда - світ неодухотвореного. Однак такі протиставлення в поетичному космі Антонича співіснують не як антоніми, а як взаємодоповнення, взаємопроникні та взаємозумовлені елементи. Поезія Антонича в історії української літератури - явище непересічне. Осягнути його прагне вже котра генерація дослідників, а поет досі зостається невідкритим, «незнаним» [7]. Критики відносять Антонича до поетів із яскраво вираженим «діонісійським» началом, яке має наступні ознаки: ірраціональність мислення; розкутість асоціацій; домінуючі оргаїстичні мотиви; земні втіхи поруч із тонким усвідомленням жертовності самого життя. Але «трагізм долі (Антонича) виявився й у повному замовчуванні цього поета, яке тривало більше, ніж він прожив» $[9$, с. 7].

Творчість Антонича не набула широкої популярності та гідної літературознавчої оцінки. Радянське літературознавство занесло поета до «крамольних» галицьких суспільних та культурних діячів як «прислужника буржуазії та реакційного клеру». Грунтовна монографія М. Ільницького (1968р.) вийшла аж через двадцять років. Лише в незалежній Україні доробок Антонича був поцінований. Першим звернувся до вивчення його творчого спадку Д. Павличко. У статті «Пісня про незнищенність матерії» автор розкриває характерні особливості поетики творів Б.-І. Антонича, висвітлює філософське розуміння поетом єдності світу, оригінальне переосмислення 
язичницьких вірувань і фольклорних мотивів [12].

Особливо слід звернути увагу на актуальність студій, присвячених Антоничу. Структурно складний (але неподільний) код його доробку, цілісна система наскрізних образів-символів, мотивів, тенденцій та нашарувань, прогресивний розвиток, розгортання окремих архетипних конструкцій до рівня сенсобуттєвих не дають змоги говорити про можливість одноактного «розкриття», декодування. Вагомий внесок, зокрема М. Ільницького, який у розвідці «Образ нічного неба...» зробив спробу компаративного дослідження поезії Антонича та М. Шашкевича, Ф. Г. Лорки, I. Калинця [6]. У низці статей («Філософія «бронзових м'язів», «Осягаючи феномен Антонича») літературознавець окреслює провідні мотиви творчості митця, доводить самобутність лірики [4; 5].

Високо оцінили Антоничеву лірику «пізні шістдесятники» I. Калинець, Г. Чубай, Т. Мельничук, Я. Павуляк. За словами Юрія Андруховича, «творчість, як і загалом уся загадково-трагічна, мічена комплексом Шеллі, постать Антонича справила особливий вплив на поетичне формування поетів «київської школи» і цілком «містичний», культовий - на деяких вісімдесятників (В. Герасим'юк, І. Малкович, П. Мідянка, В. Неборак та ін.), для яких це вже не стільки текст, скільки своєрідний «медіум-посередник» [1, с. 135].

Виходять у світ збірка есе, спогадів, листів «Весни розспіваної князь» за редакцією М. Ільницького та Р. Лубківського, вартісні монографії, низка статей у періодиці, де постає образ митця, позбавлений тоталітарної заангажованості. Утім, незважаючи на безперечні досягнення у вивченні дивосвіту письменника із Західної України, його поетика досліджена найменше. Багата на архетипні образи та коди лірика, завдяки своїй чуттєвій доступності, є матеріалом для аналізу поняття «архетип» i дотичних літературознавчих категорій. Твори поета включені до шкільної програми, тому актуальність дослідження втілюється в теоретиколітературознавчій та методолого-практичній площинах. 
Мета статті полягає в тому, аби осмислити філософську концепцію єдності світу, розкрити самобутність поетичного мислення Б.-І. Антонича, екзистенційне наповнення архетипних структур віршів.

Модерність лірики Антонича як знакової системи стала підгрунтям для творення своєрідного «міфу» на основі осмислених i переосмислених ним архетипів. Зокрема, феномен Гармонії - не канон, догматично окреслена категорія існування, а багатовимірний процес, укорінений у самому факті вселенського буття; топос Міста не територія, коло матеріальних об'єктів, а плодюча та вбивча семіотична таїна, осмислити та опанувати яку належить.

Для аналізу перехідних архетипних структур, образів та моделей Антоничевого світу опорними можуть уважатися ті смислові дефініції, які продиктовані специфікою етнічно закріпленого, вкоріненого в національній свідомості уявлення про первні буття. Авторська особистісна метафорика, нашарування сенсів сутнісно не спотворює жоден із українських архетипів, одна надає йому нових обертонів, виводить на якісно інший рівень функціонування - вже не як стертих образів народної звичаєвої свідомості, а як ключ до пізнання трансцендентного, як опертя для екзистенційного досвіду поета.

Оцінювати творчість митця як беззаперечне свідчення генія (згідно з позицією Дмитра Павличка, Богдан-Ігор Антонич є «одним 3 українських поетичних геніїв XX ст.» [12]) дає змогу об'єктивна цілісність творчого доробку, відчутне прагнення відбиття в поезії мікро- та макрокосмів особистісного й етнічного буття. Адже його «метафори ведуть до усвідомлення духовного, вищого й незбагненного начала в людині, а саме осмислене буття він малює як пробуджувану таємним провидінням волю до творчості» [12].

Архетипні конструкції, що головно представлені в доробку Антонича як концентри символіко-образних підсистем, у цьому зрізі дослідження творчості продукують інтерес та мають вагоме значення в подальшій оцінці лірики, оскільки представляють не тільки і не стільки тематичне розмаїття сюжетів, тем, скільки відбивають 
специфіку філософсько-метафізичного коду, витвореного поетом на підвалинах першообразів.

Наразі наукову цінність становить аналіз поетики Антонича через виокремлення систем образів-архетипів та дослідження структурних зв'язків між ними. Міфопоетичний аспект проникнення дає змогу продемонструвати гнучкість і релевантність літературних архетипів митця. Проблема художнього віддзеркалення і трансформації базових архетипів у конкретному літературному творі $є$ однією із найбільш актуальних у дискурсі сучасних досліджень. Архетипні прототипи або «праформи», як їх визначав К.-Г. Юнг, що є проявом «колективного несвідомого», відображаються в міфології, релігії, мистецтві.

У першій половині XX ст., у руслі психоаналізу 3. Фройда, науковці активізують пошуки, досліджуючи відлуння міфопоетичної свідомості (структурна антропологія - К. Леві-Стросс, міфо-ритуальний підхід - Дж. Фрезер, етнографічний - Л. Леві-Брюль, символістський Е. Кассирер). Теоретичний заділ Е. Мелетинського (друга пололовина $\mathrm{XX}$ ст.) продукує поняття літературного архетипу, а елементи міфопоетичного аналізу, серед іншого методологічного інструментарію, мають нині місце як один із аспектів загальної поетики.

Зоря, Пісня, Земля, Ліс, Вода, Трава, Сонце, Ніч, Камінь, Перстень, Тварина в міфопоетичній площині $є$ фундаментальними архетипами традиційного українського сакруму на всіх рівнях (психологічному, загальнокультурному i т. ін.). Вони домінують, ураховуючи частотність їх вживання в народнопоетичній творчості та корпусі класики, і в літературно-художньому доробкові митців ХX ст. У творчості Б.-І. Антонича прослідковується розлогий масив значень $\mathrm{i}$ смислів навколо стрижневих архетипів. Вони невіддільно вплетені у контекст образної структури сем суто українського і загальнолюдського рівня та закодовані у специфічній манері. Однак говорити про використання архетипу як готового кліше, витвореного народною свідомістю, не доводиться. У ліриці Антонича домінує активний буттєво-вітаїстичний авторський початок; відповідно 
міфопоетичне ядро того чи того архетипу зазнає значної концептуальної «напруги» усієї системи художніх координат.

Поезії Антонича ілюструють модерністську аксіологічну парадигму початку XX століття. Тим більше аналізу потребує підхід щодо сучасного прочитання гуманістичного й екзистенційного наповнення архетипів, висвітлених одним із найбільш загадкових i суперечливих поетів.

Поезія «Автобіографія» 3 першої збірки «Привітання життя» слугує неабияким прикладом використання архетипів «Сонце», «Місто», «Пісня», які стали рефренами поетичної картини світу митця: У горах, де ближче сония, перший раз приглянувся небу, / тоді щзось дивне й незнане пробудилось у мені / й піднеслася голова й слова прийлли до уст зелені [2] Діалектичний дуалізм «сонце - небо» як нерозривна єдність, створюють у цих рядках просторовий континуум - архетип Сонця у площині художнього твору має власний функціональний різновид. Тут Сонце $є$ центральним елементом світобудови, «оком неба», близькість до якого породжує творчий імпульс. Цей конструкт розгортається до людиноцентричної моделі, що нею ліричний герой характеризує власне «Его»: «Я все - n'яний дітвак із сонцем у кишені». Людина як мікрокосм транслює макрокосмічну ідею світла. В iї архетипній свідомості асоціативний ряд «тепло - життя», пов'язаний із сонцем. Причому образ «сонще у кишені» не позбавлений юнацької зухвалості. Це можна потрактувати двопланово: по-перше, як вияв олюднення, теоретичного наближення об'єктивного центру відомого Всесвіту до конкретного індивіда, і подруге - як, навпаки, духовного піднесення ліричного «я» до рівня вселенських утворень. Звідси - узагальнений образ, утілений у епітет «n'яний» автор віднаходить у Сонячній енергії, світлі та теплі життєдайне опертя для творчості («слова прийшли до уст»), для розгортання екзистенційного пошуку і самоусвідомлення.

Архетип Пісні, утілений у прикінцевій сентенції «Мої nicнi - над рікою часу калиновий міст», уведено у своєрідний афористичний ( ) Ж. М. Свірська, 2016. 
висновок про роль поезії. Для авторського ліричного світу характерним $\epsilon$ зіставлення поезія - Пісня аж до абсолютної синонімії та взаємозаміни. Образ цей багатоплановий: поданий у тісному зв'язку 3 народною традицією (міст - калиновий; тут очевидне звертання до традиційної рослинної символіки), він виступає як засіб ствердження індивідуальної значущості особи, суб'єктивного усвідомлення первнів, на яких грунтується процес творчого осмислення буття. Через Пісню ліричний герой пізнає світ. Хронос архетипу зміщений відповідно до характеру осягнення місця індивідуальної екзистенції у процесі творення - Пісня Антонича лунає «над рікою часу».

Поява в першій книзі поезій «поряд із науково-технічними та спортивними віршами поезій «Балада про тінь капітана», «Ідеал», «Алхімія», «Підсвідомість», на думку І. Бетко, засвідчують «зростання самосвідомості ліричного героя» [3, с. 13].

Один із найбільш уживаних у світі Богдана-Ігоря Антонича архетипів - Сонце. Поету аж закидають: «Образ сонця експлуатується в такій мірі, що його застосування починає межувати 3 марністю» [14, с. 125]. Однак, на думку М. Ковальчука, «сонцепоклонництво» Б.-І. Антонича тільки підкреслює індивідуальний стиль поета, вирізняє його твори 3-поміж інших» [8, с. 103]. Тісний зв'язок як із міфологемними концентрами народного світосприйняття, так i 3 модерною тенденцією до розуміння прихованих у архетипних кодах смислів, роблять створений образ Сонця особливо вагомим.

Трактування архетипу Сонця широке, міфологема «сонце» наповнюється відтінками емоційно-експресивного змісту. Більше того, солярні архетипи в поезії $\epsilon$ не тільки міфологічною персоніфікацією космічного тіла, а «поетичними образами, що уособлюють найрізноманітніші переживання, емоції людини. Поняття добра і зла, щастя і горя, радості і суму нерідко конкретизуються через ці слова-образи» [8, с. 103]. Ця архетипна структура стає в міфосвіті Антонича стрижнем для численних образних експериментів: «дівчатам заплітають у волосся сония гребінь», сонце ходить у 
крисані, його і на плечах носять, і запрягають до теліги, воно поринає у дзбаник, а спати ходить до криниці, пливе рікою, це - і стріла, і сніг, і цегла. Притому центральний образ-архетип постає перед читачем у такій багатогранності видів, знаків та форм, яка поетапно кристалізує синтетичний мисленнєвий концепт Сонця як центру не лише осібного, а й загальнолюдського буття. Сонце - «годинник $i$ таріль» - первні життєдайної сили, наснаги, творчої енергії. Це й дало підставу для найменування поета «сонцепоклонником».

Себе поет характеризує так: «розсміяний $i$ босий хлопчина 3 сонцем на плечах»; «Я, сонцеві життя продавщи / за сто червінців божевілля...» [2]. В обмін на життя сонце обдарувало творчими чарами. Архетип Сонця в цій програмовій поезії набуває рис теоцентричного характеру. Сонце як божественна сутність, здатна контролювати людське буття, що безконфліктно межує із Его ліричного героя. Істотна риса такого союзу, який виникає у свідомості «Я»-автора - його креативна спрямованість, абсолютом якого стають «червінщі божевілля». Божевілля $\epsilon$ станом фактично неконтрольованого, не до кінця осмислюваного і тому природного творчого акту. Натхненне сонячною силою, воно сприймане поетом як абсолют конструктивного начала.

У Карпатах гуцули, лемки, бойки зазвичай позначають хати хрестом у колі. Цей оберіг замкнений, не має ні початку, ні кінця: Хай сонце - прабог всіх релігій - / золотопере ци життєсійне, благословить мій дім крилатий. / Накреслю взір його неземний, / святий арійський знак таємний, / накреслю я його на хаті / $i$ буду спати вже спокійно («Молитва»). В Антонича «обрій узором кола вчить про досконалість міри» («Ars poetika»). Звідси - «коло рівних строф», «nісні коло», плетення пісні, що «натхненним кружля веретеном» символ вічності. Наразі випливає ідея незнищенності мистецтва.

Витоком творчості Богдана-Ігоря Антонича є перстень як варіант кола: перстень пісні («Елегія про перстень пісні»), перстень молодості («Елегія про перстень молодості») та перстень ночі («Елегія про перстень ночі»). Передумовою трьох перснів знову є тріумвірат: Крилата скрипка 
на стіні, / червоний дзбан, квітчаста скриня («Три перстені»). Предмети творчості - символи творчого сп'яніння. Метафоричний образ персня модифікує архетипні солярні мотиви творчості. Перстень - символ певного світу, тобто сфери, у якій проявляється той чи той стан існування, символ безперервності, вічного кругообігу часу.

Можемо твердити, що поетичне «я» Антонича живе у трьох світах - світі пісні, світі молодості й світі ночі. Світи існують кожен зокрема й водночас у свідомості поета зведені воєдино. Натяк на цю єдність є у «Трьох перстенях», де знаходимо квітчасту скриню 3 трьома перстенями в ній, що, як кожне сховище, служить тут, правдоподібно, символом творчої уяви або підсвідомості поета.

Отже, архетип Сонця розкрито у творчості Антонича багаторівнево; утілений у значних модифікаціях, він постає стрижневим, концентричним поняттям для осягнення міфопоетичного світу лірики.

Мотив символічного весілля митця 3 власною поезією має свої витоки: Почалось так: упився я / від перших власних строф похмілля. / Був тільки місяць дружбою / на мому з піснею весіллі. Знаменно, що в купальських і весільних піснях, у вітчизняній традиції тлумачення символом нареченого є місяць-молодик: Неначе в книгах праарійських / підкова, човен і стріла. / В діброві сяє срібне військо, / шумлять санскритськії слова. Місяць постає в подобі підкови - його перекували ковалі. Човен, підкова, серп, меч - це образи місяцямолодика в космогонічних колядках. Антоничівські «стріли зір на вишині», таємничі, «немов знаків санскритських ряд», поруч із місяцем-повнею виражають ідею творчості за прообразом нічної містерії Різдва Світу. У поєднанні з місяцем-молодиком вони стають небесним світлим військом, яке долає морок небуття: «вечір платить дневі червінцем зорі».

За міфопоетичною концепцією Антонича, зміна подоби світил відбувається завдяки тому, що космогонічне начало зустрічається iз хтонічним, занурюється в нього й оновлюється. Виразна ознака землі iii хтонічність. А хтонічні істоти пов'язані 3 потойбіччям та смертю 
[11, с. 268-274]. Оптимістичність грецької міфології, яка позначилася на образності поезії Антонича в тому, що світлі боги-олімпійці таки утверджують світопорядок, хоч хтонічне начало до кінця й не подолане. Архетипний рівень осягнення цих праструктур характеризується в поета сутнісно гармонійними, творчими імпульсами, що їх ліричний герой спрямовує до представлених із ним на рівних світил («був місящьь дружбою»). Образи олімпійських богів, які стали засобом творення ілюзії порядку, космосу, що рятує людину від тиску праволі на міру та форму, пов' язуються в ліриці з «аполонівським» світосприйняттям.

Навіть при зануренні ліричного героя в докосмогонічні глибини не зникає образ світотворчого вогню блискавки. Через таке поступове заглиблення осягається первісна єдність буття. За баченням О. Пономаренко, цей процес відбувається так: «перша стадія перетворення в рослину. Рослини передують людському існуванню. За українськими космогонічними колядками, посеред моря уже росло дерево до того, як був створений світ. За «Книгою Буття» Біблії, перша людина (Адам) створена у Божому райському саду. За антоничівською есхатологією, рослини пануватимуть і в кінці, після зруйнування людської цивілізації [13, с. 109]. Друга стадія - метаморфоза в камінь. Це i є той міфологічний камінь-алатир, білий камінь, 3 якого, за космогонічними колядками, постала астральна тріада. Спільний мотив балад, гаївок і купальських пісень - накопати коріння 3-під білого каміння - означає пробудити любов, а зокрема, пробудити землю до родючості, поєднавши ії з небом [13, с. 110].

Архетип Ночі також посідає чимале місце у світі антоничевої лірики. Антонича бентежить бінарна опозиція одвічних понять: дочасне і безсмертне. Ніч - та пора, яка передувала існуванню світу, спалах вогню - мить, коли проявляється могутня життєва енергія, здатна створити світ. Ця магічна купальська ніч, коли можуть здійснюватися заповітні мрії та бажання, настає після найдовшого в році дня літнього сонцестояння. На Купала Сонце досягає своєї повної сили, а земля під ним, пробуджена до родючості Перуновою гілкою- 
блискавкою, - найбільшого розквіту, тому виявляються іiі цілющі сили, здатні наснажувати все чудодійними можливостями й натхненням: Змія, мов рожа, гребеняста / росте з-під каменя кущем. / Слова рослинні і хвилясті / злітають радісним дощем («Змія»).

Розквіт пробудженої природи асоціюється 3 творчістю. Поєднання землі і неба через спалах блискавки виражається дощем, який спричиняє шал розвитку рослин. Миттєве і раптове осяяння викликає натхненний стан. В естетиці Б.-І. Антонича дощ є метафорою поезії, призначення якої - уславлювати буяння буття у Всесвіті.

У струмені сновидіння та мрії зринає друга дійсність мистецтва, «кращза від тої з-за шиб». Тут архетипне світобачення ліричного героя сягає рівня епістемологічної концепції - пізнання дійсності відбувається на рівні засвоєння та прийняття чи відторгнення архетипних структур, що характеризують дійсність.

Міфи, фольклор, поезія різних народів і часів окреслюють мотиви перетворення. Так викристалізувалися в єдине поняття метаморфози на кшталт цар і лев, воїн і дуб, дівчина і калина, парубок і сокіл і т. ін. У «Зеленій Свангелії Антонич робить висновки: Лисиці, леви, ластівки і люди, / зеленої зорі черва і листя / матерії законам піддані незмінним, / як небо понад нами, синє і сріблисте!

Язичницьке бачення природи як першоджерела людини в поезії Антонича зливається 3 уроками, даними Уїтменом. «Тобі хвала, сивобородий міністре республіки поетів, Уолте Вітмене, щзо навчив ти мене молитися стеблинам трави, - пише Антонич. - В корчмі «Під романтичним місячем», п'ючи палючу $i$ похмільну горілку мистецтвва, разом з тобою звеличую найтайніше $i$ найдивніше явище: факт життя, факт існування». Я розумію вас, звірята і рослини, / я чую, як шумлять комети $і$ зростають трави. / Антонич теж звіря сумне $i$ кучеряве» («До істот з зеленої зори»). Тут велетенська здатність душі входити в таємниці природи, відчувати інтелектуальне впокорення перед iї величністю, разом із тим світло і височину розуму перед ницою байдужістю й темрявою природи. 
Одним із центральних у ліричному світі Антонича став образархетип Міста, який виник у рядках: $A$ як зійшов із гір до гамірливих міст, / у злиднях і невдачах не кляв ніколи долі та не ганив, / глядів спокійно. Дихотомія гори-місто протиставляється у світлі антонімічності ознак. Асоціативне коло «гори» передбачає опорні локальні центри: «ближче сонияя», «небо», «дивне», «незнане», «піднесення», «зелень», у той час як «місто» формалізується в семах «злидні», «невдачі», «хвиль противних гурагани». У подальшому з'являється гамірливий праобраз урбаністичного осередку. Освоєння топосу здійснюється ліричним героєм без остраху. Остаточно не окреслений, цей образ, однак, має риси, що стануть притаманні йому в пізніших творах Б.-І. Антонича позачасовість, надбуттєвість: Місто - як прояв Вічного; «божественна руйнація» антропоцентричного світобачення мешканців: Місто, винищуючи, немовби зачаровує ліричного героя, не відпускаючи, труїть його. Онтологічна амбівалентність образу Міста провокує сутнісні зміни в тональності всієї настроєвої палітри митця, продукуючи екзистенційно трагічний характер пізньої лірики.

Отже, під впливом історичних і суспільних змін будь-який архетип, оприявлений у літературному доробкові, розкриває актуальний, позачасовий зміст, «умонтований» у художній замисел $\mathrm{i}$ реалізований у поезіях. Образи-архетипи, глибоко вкорінені в особистісну свідомість ліричного «Я», слугують відправними точками для нанизування асоціацій, міфологемних кодів різного рівня узагальненості, етнічно-національних та культурних ремінісценцій. Змістовність, складна символіко-образна структура, вишукана метафорика, вибагливі часово-просторові химери дають змогу отримувати від творів Б.-І. Антонича істинне естетичне задоволення.

\section{Література}

1. Андрухович Ю. Велике океанічне плавання Б.-І. Антонича. / Ю. Андрухович // Всесвіт. - 1990. - № 2. - С. 135-141.

2. Антонич Б.-І. Велика гармонія : (Модерністична поезія XX ст.) / Б.-І. Антонич ; упоряд., передм., прим. Д. В. Павличка. - К. : Веселка, 2003. - 350 с.

3.Бетко І. Лірика Богдана-Ггоря Антонича у дзеркалі аналітичної психології Карла(С) Ж. М. Свірська, 2016. 
Густава Юнга / І. Бетко // Слово і Час. - 2003. - №2. - С. 7-13.

4. Ільницький М. Філософія «бронзових м’язів» [90-річчя від дня народження Б.-І. Антонича] / М. Ільницький // Дивослово. - 1999. - №10. - С. $2-7$.

5. Ільницький М. Осягаючи феномен Антонича / М. Ільницький // Урок української. -2001 . - №2. - C.48-53.

6. Ільницький М. Образ нічного неба : [архетип місяця в поезії Б.-І. Антонича, Ф. Г. Лорки та І. Калинця] / М. Ільницький // Дивослово. - 2003. - № 10. - С. 2-5.

7. Калинець I. Знане і незнане про Антонича : матеріяли до біографії БогданаІгоря Антонича / І. Калинець. - Львів : Друкарські куншти, 2011. - 276 с.

8. Ковальчук М. Міфологічні персоніфікації космічних тіл, явищ природи у мовно-поетичній традиції Б.-І. Антонича та О. Олеся / М. Ковальчук // Український смисл. - 2008. - С. 102-109.

9. Логвіненко Н. Український образ світу в творчості Богдана-Ггоря Антонича / Н. Логвіненко // Українська література в загальноосвітній школі. - 2008. - №4. - С. 7-10.

10. Новикова М. Міфосвіт Антонича // Б.-І. Антонич. Вибране / М. Новикова. К. : Київська правда, 2003. - С. 5-18.

11. Мифология : Иллюстрированный энциклопедический словарь / Ред. Е. М. Мелетинский. - СПб. : АО «Норинт», 1996. - 844 с.

12. Павличко Д. Пісня про незнищенність матерії / Д. Павличко // Антонич Б.-І. Пісня про незнищенність матерії. Поезії. - К. : Рад. письменник, 1967. - С. 7-46.

13. Пономаренко О. «Дивіться: це пожежа світу, буря первнів...» : Межовий час у поезії Б.-І. Антонича / О. Пономаренко // Українська мова й література в середніх школах, гімназіях, ліцеях та колегіумах. - 2011. - №7-8. - С. 105-113.

14. Рубчак Б. Поетичне бачення землі: три слов'янські варіанти / Б. Рубчак // Весни розспіваної князь. - Львів, 1989. - С. 125.

Стаття надійшла до редакиії 30.11.2016 p. 